\title{
ORIGIN OF IRON ORE NUGGETS ("BOHNERZE") THROUGH WEATHERING OF BASALT AS DOCUMENTED BY PEBBLES FROM THE HERBSTLABYRINTH, BREITSCHEID-GERMANY.
}

\author{
NASTANEK ŽELEZOVIH KEP (BOBOVCA) \\ PRI PREPEREVANJU BAZALTA: ŠTUDIJA PRODNIKOV \\ V JAMI HERBSTLABYRINTH, BREITSCHEID, NEMČIJA
}

AHMAD AL-MALABEH ${ }^{1} \&$ STEPHAN KEMPE $^{2}$

\footnotetext{
${ }^{1}$ Ahmad Al-Malabeh, Hashemite University, Department of Earth and Environmental Sciences, P.O. Box 150459, Zarka 13115, Jordan; Am@hu.edu.jo

${ }^{2}$ Prof. Dr. Stephan Kempe, University of Technology, Institute of Applied Geosciences, Schnittspahnstr. 9,
} 


\title{
Abstract
}

UDC: $553.3: 551.3(430)$

\begin{abstract}
Ahmad Al-Malabeh \& Stephan Kempe: Origin of iron ore nuggets ("Bohnerze") through weathering of basalt as documented by pebbles from the Herbstlabyrinth, Breitscheid-Germany.
\end{abstract}

This study was conducted to investigate the origin of the iron nuggets that have been found in the Herbstlabyrinth at Breitscheid, northern Hessen/Germany. A total of ten pebbles were collected. Petrographically, the pebbles can be divided into three groups: rather fresh basalts, markedly or totally altered basalt (including the iron nuggets) and a dark sandstone. The iron nuggets originate through a progressing alteration (oxidation and hydration) of the basaltic pebbles. The geochemical study shows that the original fresh basaltic pebbles are of alkali type and belong to the Na-series. The magma that gave rise to them was primitive and originated in peridotite mantle source.

Key words: Iron nuggets genesis, cave sediments, basalt, pebbles, karst deposits, weathering.

Izvleček

UDK: 553.3:551.3(430)

\section{Ahmad Al-Malabeh \& Stephan Kempe: Nastanek železovih kep (bobovca) pri preperevanju bazalta:} študija prodnikov v jami Herbstlabyrinth, Breitscheid, Nemčija

Namen te študije je bila raziskava izvora kep železa, ki so bile najdene v Herbstlabyrinthu pri Breitscheidu, severni Hessen/Nemčija. Vsega skupaj je bilo zbranih deset prodnikov. Petrografsko prodnike lahko razdelimo v tri skupine: precej svež bazalt, opazno ali popolnoma preperel bazalt (vsebuje železova zrna) in temen peščenjak. Železova zrna izvirajo iz procesa preperevanja (oksidacija in hidratacija) bazaltnih prodnikov. Geokemična študija je pokazala, da so izvorni prodniki bazalta alkalnega tipa in da pripadajo Na-seriji. Magma, iz katere so nastali, je bila nerazvita in je izvirala iz peridotitnega plašča.

Ključne besede: nastanek bobovca, jamski sedimenti, prodniki, preperevanje. 


\section{INTRODUCTION}

Iron ore nuggets ("Bohnerze" in German) are a wide-spread, continental type of iron deposit, These deposits are mostly of small extent and seem to be specifically associated with carbonate landscapes (e.g., Bartz, 1957). It is therefore not unusual to find iron ore nuggets in karst depressions and in caves; for example in Germany in the Harz Mountains, in the Weserbergland, in Hessen and in caves of the Frankonian and Swabian Albs, and in Austria in the Dachstein caves. Typically, the nuggets are a few centimeters large, rounded or elongated with pockets, dark brown in color, and can be highly polished if found in cave streams.

\section{ORIGIN OF NUGGETS}

So far, nodules found in caves have been attributed to the oxidation of pyrite or markasite (Hill \& Forti, 1997). In the upper Jurassic limestone of the Frankonian and Swabian Albs pyrite nodules occur often. When these are slowly oxidized within the rock, the outer crystal forms of pyrite can be preserved, thus betraying the origin of the limonite as product of pyrite oxidation (limonite pseudomorphs after pyrite). An example of such a limonite nodule is given in Fig. 1. Once the limestone around is dissolved, the nodule is free for further water transport and shaping by erosion, thus explaining their occurrence in caves. In the Dachstein Caves, Austria, pyrite forms within the sediments which are then also oxidized forming such nuggets within the cave (e.g., Seemann, 1979).

Here we can demonstrate that iron ore nuggets found in caves can be formed by another process as well: through the gradual weathering of basalts.

\section{LOCATION}

The site where these nuggets occur is the Herbstlabyrinth at Breitscheid, northern Hessen, Germany. It is part of the Breitscheid-Erdbach system discovered in 1993 and forms an extensive (ca. $5 \mathrm{~km}$ long) vadose cave of complex morphology, developed in massive upper Devonian limestone of the Iberg fazies (Dorsten et al., 2005). Its genesis is associated with the sinking of small creeks which collect on the hills to the north and east of the limestone outcrop. The creeks quickly sink to the level of the karstic spring at Erdbach and have developed wide, meandering canyons, in parts interrupted by breakdown chokes. The limestone outcrop is surrounded by volcanic rocks: to the east and south we find Upper-Devonian diabases (chlorite containing basalts) and to the north and east Tertiary basalts belonging to the eastern slope of the Miocene Westerwald volcano (Kayser, 1907). Underneath the Tertiary basalts a layer of clay occurs, which serves as a spring horizon. The creeks therefore are partly groundwater-fed and may carry, when they sink after short courses, still a high $\mathrm{PCO}_{2}$ and may be specifically karst-reactive. The creeks also deliver basaltic pebbles which are transported into the cave system and deposited there. We investigated a series of such cobbles collected on $13^{\text {th }}$ November, 2004, near the Hessentunnel.

\section{MICROSCOPIC INVESTIGATION OF PEBBLES}

A total of ten pebbles were collected of which nine were cut and thin sections were prepared (labelled A-H, J). The pebbles can be divided into three groups: rather fresh basalts (A, B, C), markedly 


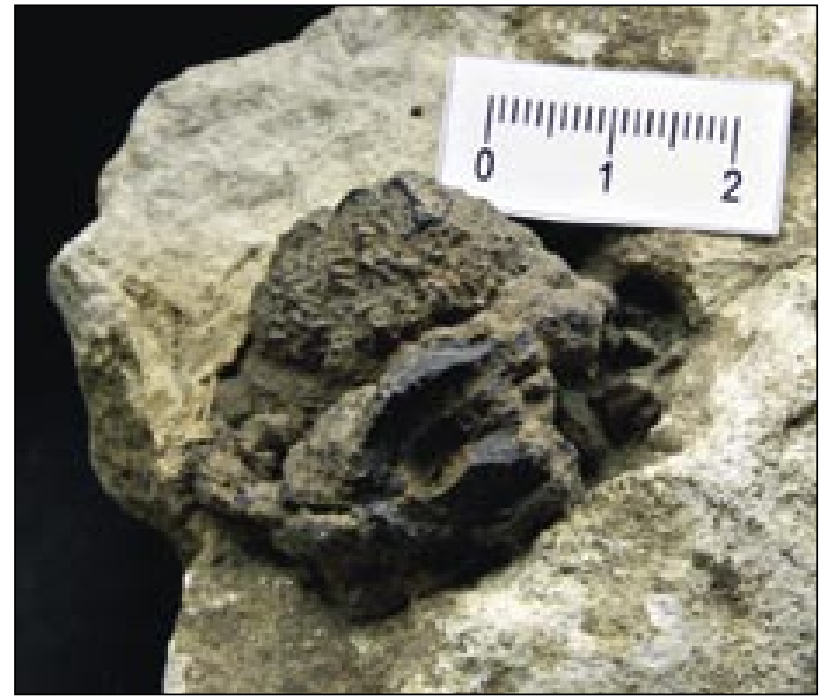

Fig. 1: A limonite nodule, pseudomorph after pyrite, which is still enclosed partly in upper Jurassic (Malm delta) limestone. Sample from Kirchleus, Kulmbach, Frankonia/Bavaria, leg. S. Kempe, 2003.

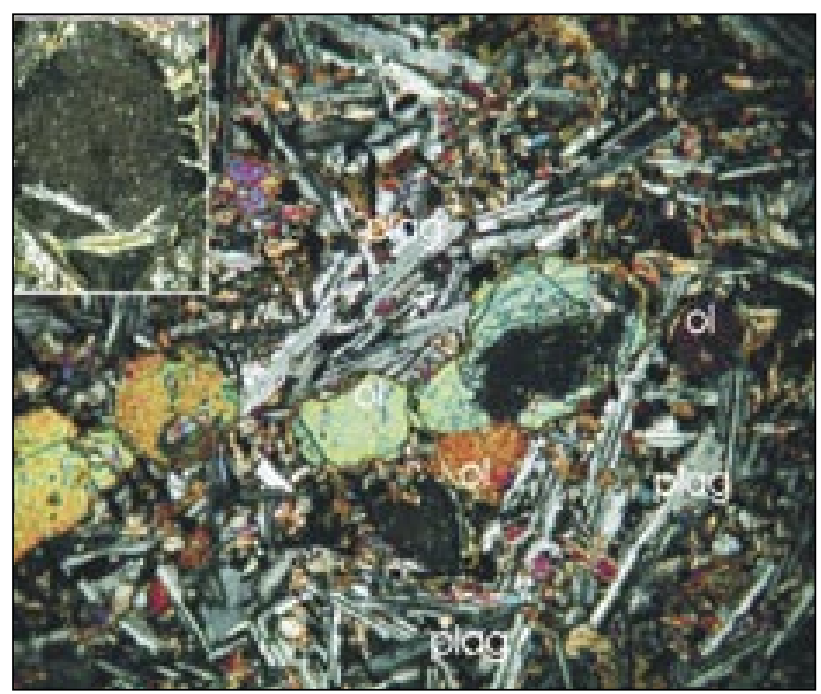

Fig. 2: Pebble A, fresh plagioclase-olivine-(enstatite) basalt. Olivines show glomeroporphyritic texture while plagioclases exhibit subpilotaxitic texture (crossed Nicols, magnification 10*4). Inset shows enstatite crystal, note: cleavage (plane light). or totally altered basalt $(\mathrm{E}, \mathrm{F}, \mathrm{H}$, J) (including the iron nuggets, J) and a dark sandstone (D).

\section{A) Fresh cobbles (Samples}

\section{$\mathrm{A}, \mathrm{B}$, and $\mathrm{C}$ )}

The fresh cobbles (A, B) are very dense, massive and slightly vessiculated basalt (Fig. 2). They are characterized by medium to fine-grained porphyritic, sub-pilotaxitic texture. Plagioclase and olivine are the essential mineral phases. The average modal composition of the rocks is: plagioclase (30-40 $\%)$, olivine (15-20\%), clinopyroxene $(15 \%)$, orthopyroxene (2\%) and opaque minerals (3-5\%). Sample C is finer grained than samples A and $\mathrm{B}$. It is slightly more weathered (particularly visible with the olivine crystals) and has more opaque minerals (5-10\%) than $\mathrm{A}$ and $\mathrm{B}$.

Plagioclase occurs in two generations as phenocrysts and small laths in the groundmass. The plagioclase phenocrysts are euhderal to subhedral. The range of extinction angles is from 29 to $24^{\circ}$, which correspond to an andesinelabradorite composition using Michel-Levy's method. The crystals are partly altered; the most common alteration product is sericite. The laths and groundmass crystals show albite twinning. They exhibit radiate glomerocrysts, and subpilotaxitic textures. 


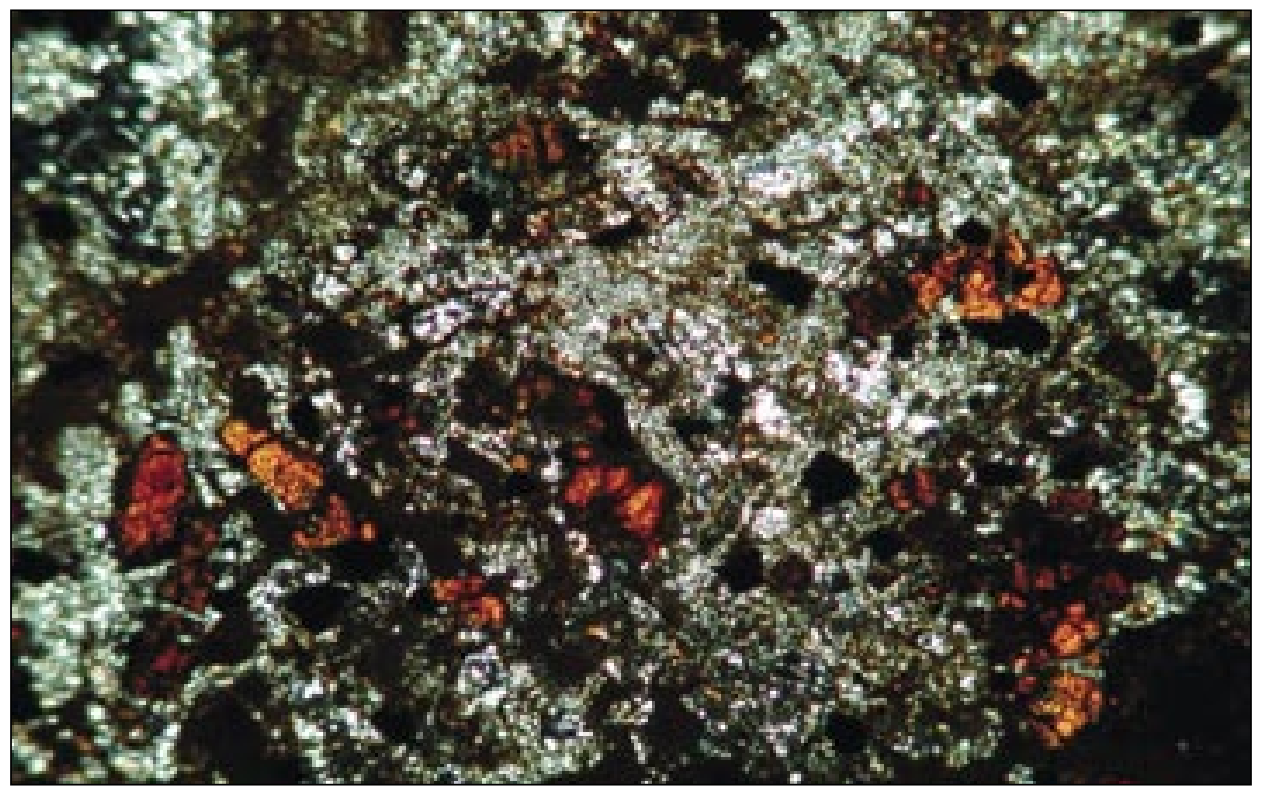

Fig. 3: Pebble G, slightly altered plagioclase-olivine basalt. Olivine is iddingsitized (rich brown core, surrounded by dark brown rims), plagioclase is converted to sericite and albite (crossed Nicols, magnification $10 * 10)$.

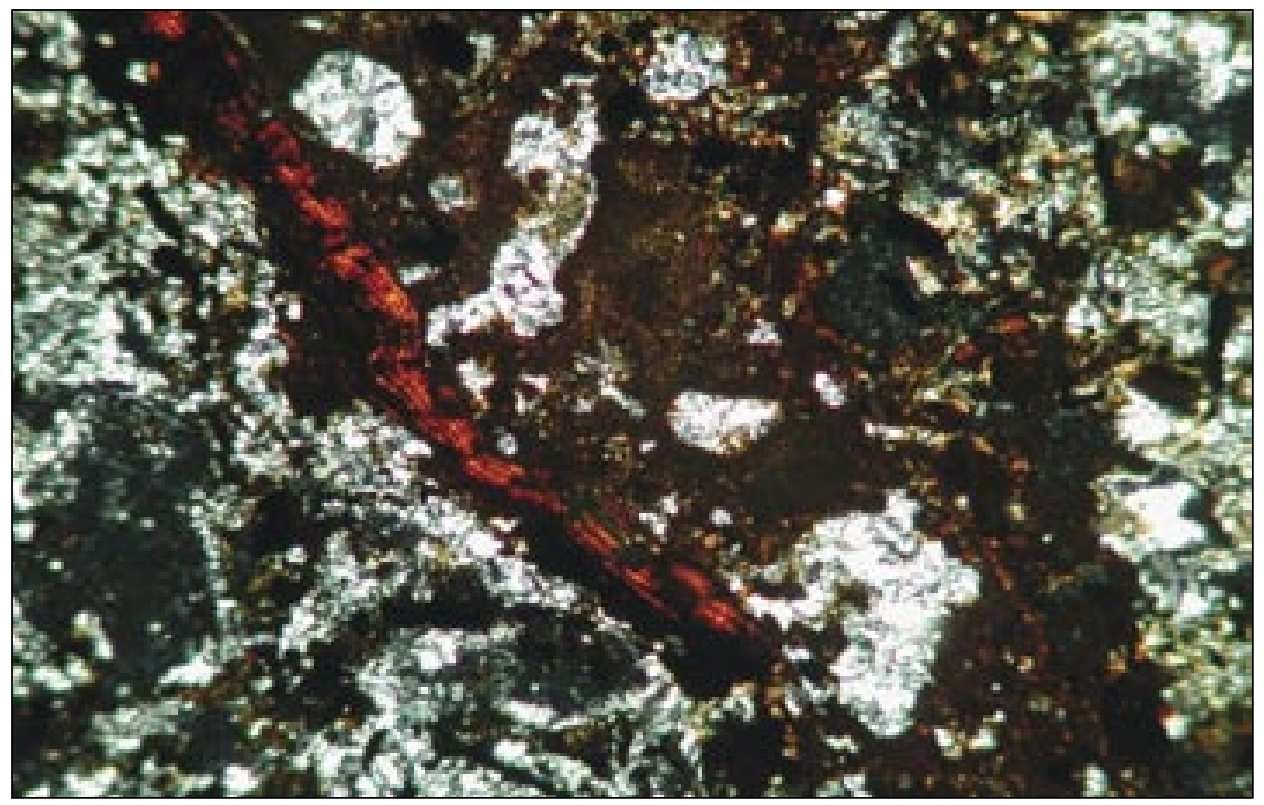

Fig. 4: Pebble E, slightly altered plagioclase-olivine basalt. Band of Fe-oxides are noticed to invade the groundmass between albitized plagioclase (plane light, magnification 10*10). 


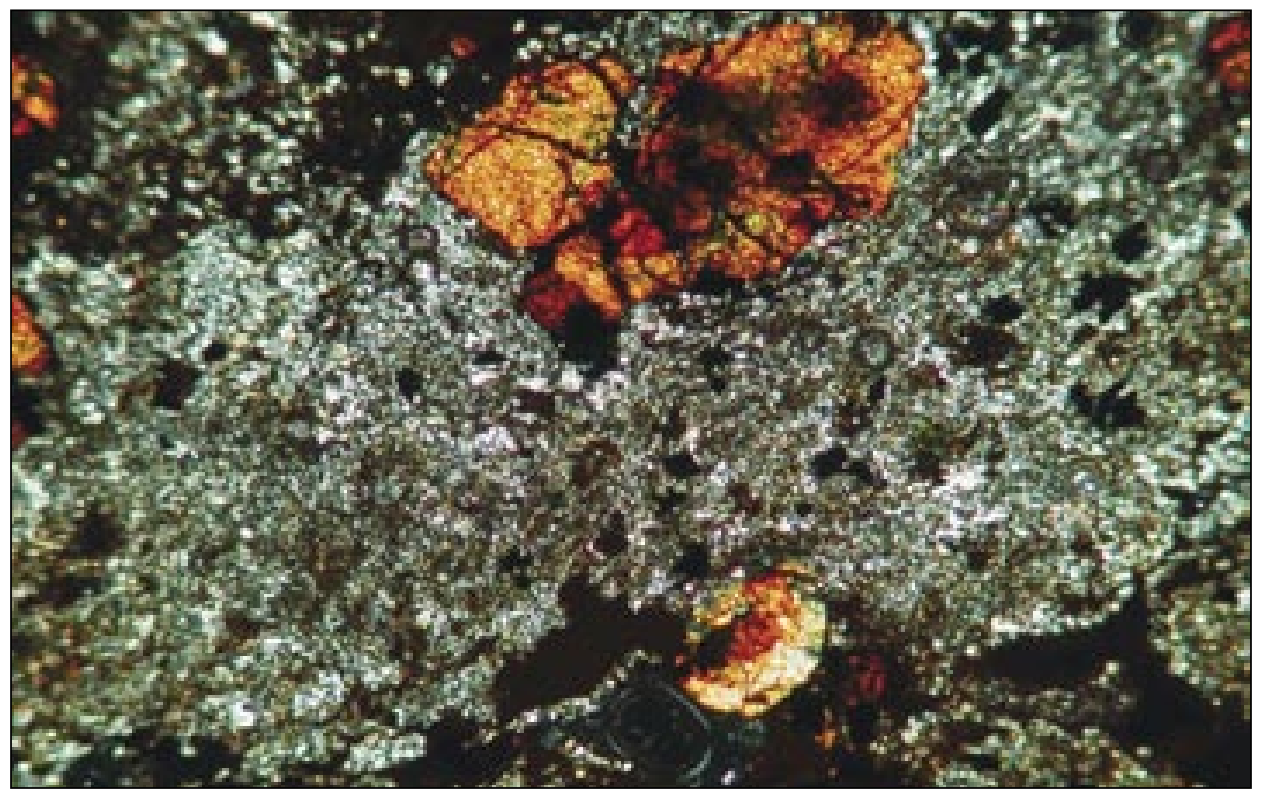

Fig. 5: Pebble F, moderately altered plagioclase-olivine basalt. Groundmass is moderately oxidized, plagioclase is moderately albitized and olivines (dark brown crystals) are iddingsitized (plane light, magnification $10 * 4)$.

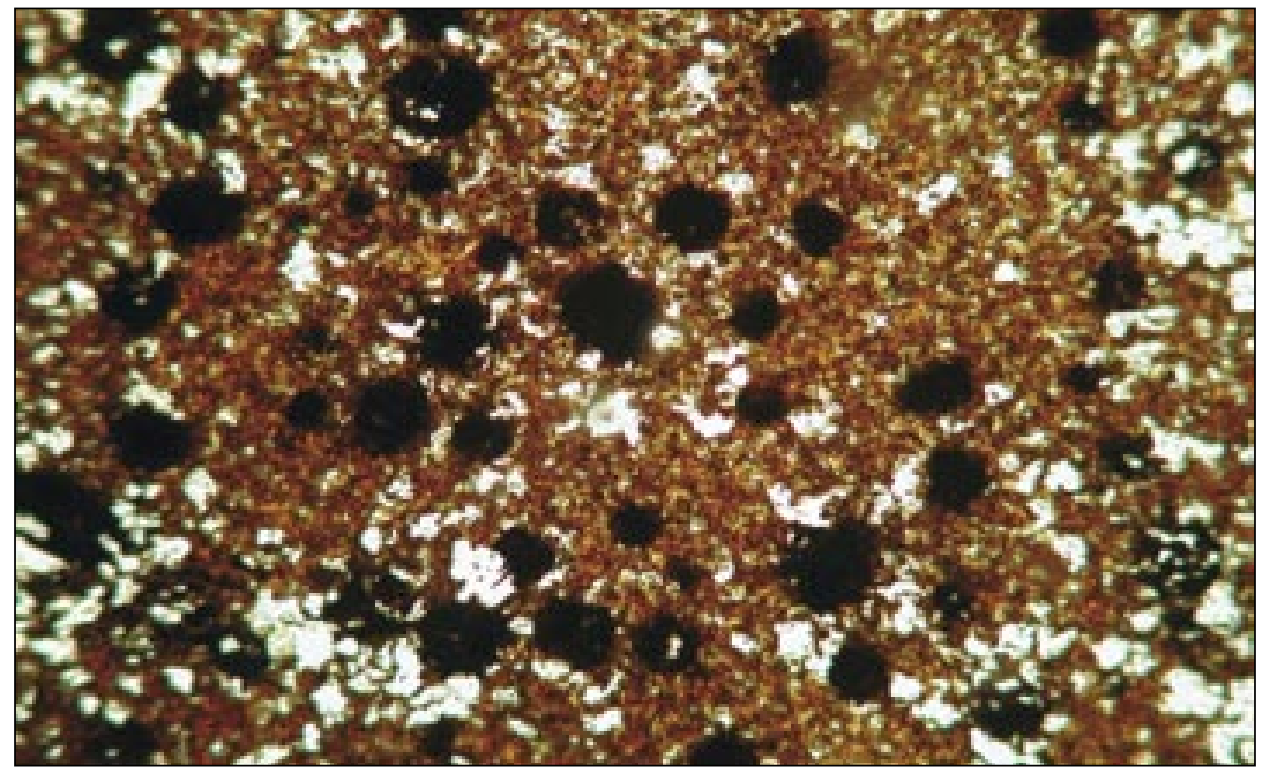

Fig. 6: Pebble J, completely altered plagioclase-olivine basalt. Groundmass is completely oxidized and palagonitized (light brown) and olivines (dark spots) are completely iddingsitized. Plagioclase is completely albitized and mostly dissolved (plane light, magnification 10*4). 
Olivine occurs in three generations that grade in size from phenocrysts to intergranular groundmass. The phenocrysts are subhedral and occur both as individual crystals and as glomerophyritic aggregate of three crystals. The crystals are highly altered to iddingsite. The iddingitization is seen to surround the margins and the innermost parts of the crystals, particularly along fractures.

The clinopyroxene contributes $10-15 \%$ of the total minerals. It occurs as brownish augite crystals that subophitically enclose clear laths of plagioclase. Together with the ground mass of plagioclase and small anhedral olivine crystals, the augite forms an intergranular texture.

Few orthopyroxene crystals of the enstatite variety are noticed in sample A (the others are enstatite-free) (Fig. 2, inset). Enstatite is distinguished by its parallel extinction and positive optic sign. The crystals are euhedral and a six-sided outline is noticed. They have two sets of cleavage. The recorded enstatite type has no pleochroism.

Opaque minerals occur as small crystals of black colors (probably magnetite). They form 3 to 5\% and are mostly euhedral to anhedral, showing square, polygonal and rod-like to irregular outlines. The crystals are distributed throughout the rock, but mainly noticed between the plagioclase laths and as inclusions in olivine. Few rounded to sub-rounded vesicles are partially filled, mostly with calcite and Fe-oxides.

These pebbles can be classified as plagioclase-, olivine-, (enstatite) basalts. Due to the missing chlorite we can be sure that the pebbles are derived from the Tertiary basalt and not from Paleozoic diabase.

\section{B) Altered cobbles (samples E, F, G, H)}

This set of pebbles shows progressive alteration of the primary igneous parent rock and its mineral assemblage. On the basis of absence or occurrence of the pyrogenic minerals (gradual increment of alteration degree), three stages of alteration are recognized:

1-Slightly altered basaltic cobbles (E, G) (Figs. 3, 4);

2-Moderately altered basaltic cobbles (F) (Fig. 5);

3-Strongly altered basaltic cobbles (H, J) (Figs. 6, 7).

The slightly altered cobbles have a brown appearance. The olivine crystals are completely altered to dark red, pleochroic iddingsites. Also, large areas of the ground mass are invaded by Fe-oxides. However, in this type, remnants of fresh plagioclase laths are still visible. In the moderately altered samples, also red-brown in color, the plagioclase is completely sericitized. The highly altered samples $(\mathrm{H}, \mathrm{J})$, dark brown to almost black in color, show a dark brown ground mass in which the iddingsitized olivines occurs as sub-rounded patches. The final products are a dense, partly banded mixture of iron-oxides with some microporphyritic feldspars (most probably albite), a material which is tough (due to the fine-grained iron-oxides) and hard (due to the little remaining albite), perfect to be polished during transport (Fig. 8).

\section{D) Sandstone Cobbles (sample D)}

The sandstone cobble at hand has a black coating. Internally, it is homogeneous, fine-grained and light to dark brown in color (Fig. 9). Bands of orange to light brown are seen to pass through the sample in different directions. Under the microscope the sandstone consists mainly of anhedral quartz clasts that form about $40 \%$ of the rock. The quartz crystals are colorless and exhibit wavy extinction. Few crystals of plagioclase (multiple twinning), orthoclase and nepheline are also re- 


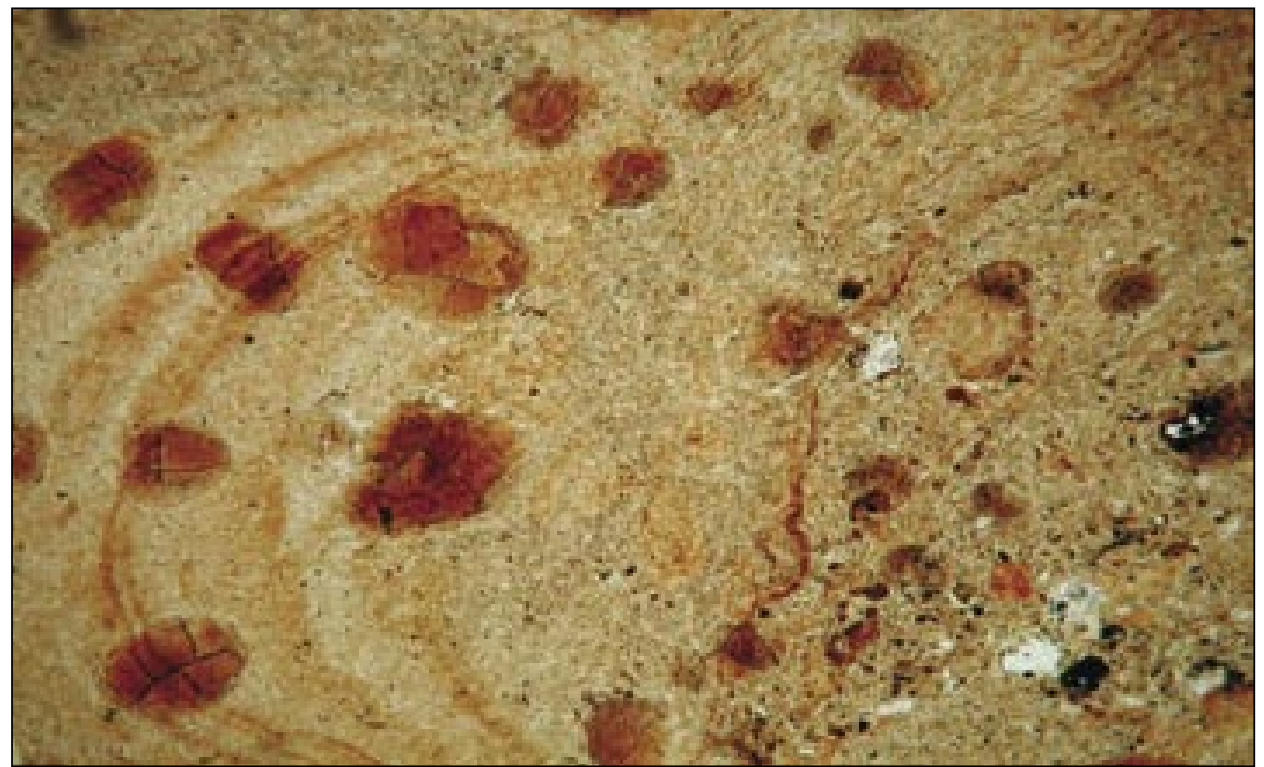

Fig. 7: Pebble H, completely altered plagioclase-olivine basalt. Groundmass is completely oxidized and palagonitized (light brown) and olivines (dark spots) are completely iddingsitized. Plagioclase is completely albitized and mostly dissolved (plane light, magnification 10*4).

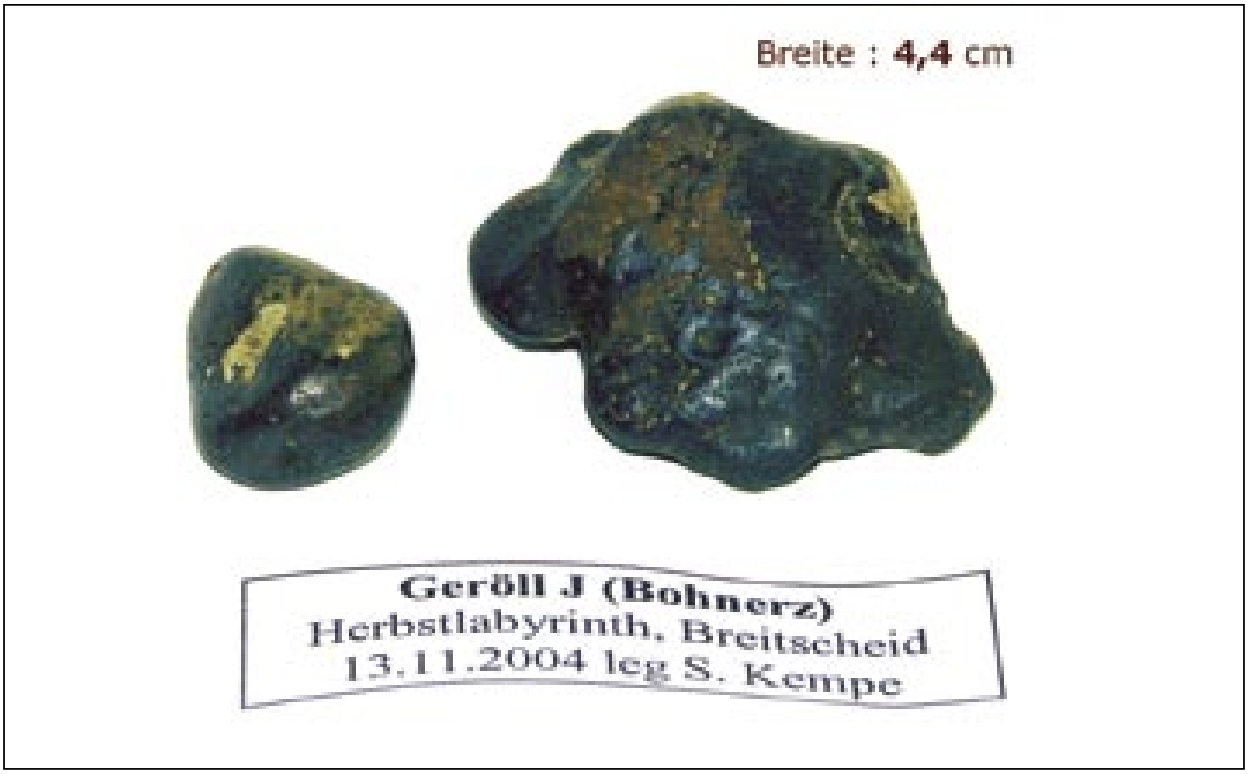

Fig. 8: Pebble J, a typical polished, dark black-brown iron ore nugget ("bohnerz") marking the final product of a long series of weathering steps, starting with a basalt. 
Ahmad Al-Malabeh \& Stephan Kempe: Origin of iron ore nuggets ("Bohnerze”) through weathering of basalt as documented by pebbles...

corded; they form up $5 \%$ of the rock. The clasts are strongly cemented by Fe-oxides of light brown and yellowish brown color (probably hematite and limonite). This matrix forms about $50 \%$ of the rock. Where this sandstone is derived from remains unclear. The mixture of pyrogenic minerals with quartz suggests it is a tuffite, a mixture of volcanic ash material with sediments. It seemingly does not fit the description of the sandstones occurring within the clay layers (Kayser, 1907).

\section{GEOCHEMISTRY OF THE FRESH ROCKS}

The fresh basaltic rock was analyzed by XRF (X-ray fluorescence) method at the Institute of Geology and Mineralogy, Erlangen University, courtesy Prof. H.J. Tobschall. The results of the main and trace elements for sample Pebble A are given in Table 1.

\begin{tabular}{|c|c|c|c|}
\hline Major Elements & $\%$ & Trace Elements & ppm \\
\hline $\mathrm{SiO}_{2}$ & 45.7 & (As) & 1 \\
\hline $\mathrm{TiO}_{2}$ & 2.27 & $\mathrm{Ba}$ & 1446 \\
\hline $\mathrm{Al}_{2} \mathrm{O}_{3}$ & 13.57 & $\mathrm{Bi}$ & $<1$ \\
\hline $\mathrm{Fe}_{2} \mathrm{O}_{3}{ }^{\mathrm{t}}$ & 12.18 & $\mathrm{Ce}$ & 41 \\
\hline $\mathrm{MnO}$ & 0.163 & Co & 95 \\
\hline $\mathrm{MgO}$ & 10.01 & $\mathrm{Cr}$ & 393 \\
\hline $\mathrm{CaO}$ & 9.68 & $\mathrm{Cu}$ & 41 \\
\hline $\mathrm{Na}_{2} \mathrm{O}$ & 2.35 & $\mathrm{Ga}$ & 20 \\
\hline $\mathrm{K}_{2} \mathrm{O}$ & 1.16 & $\mathrm{Hf}$ & 2 \\
\hline $\mathrm{P}_{2} \mathrm{O}_{5}$ & 0.349 & $\mathrm{La}$ & 16 \\
\hline$\left(\mathrm{SO}_{3}\right)$ & $<0.01$ & Mo & 2 \\
\hline$(\mathrm{Cl})$ & 0.01 & $\mathrm{Nb}$ & 31 \\
\hline (F) & $<0.01$ & $\mathrm{Ni}$ & 238 \\
\hline LOI & 1.72 & $(\mathrm{~Pb})$ & 2 \\
\hline \multirow[t]{10}{*}{ SUM } & 99.2 & $\mathrm{Rb}$ & 33 \\
\hline & & $\mathrm{Sr}$ & 516 \\
\hline & & $\mathrm{Ta}$ & $<1$ \\
\hline & & Th & $<1$ \\
\hline & & $\mathrm{U}$ & 3 \\
\hline & & $\mathrm{V}$ & 250 \\
\hline & & W & 437 \\
\hline & & $\mathrm{Y}$ & 24 \\
\hline & & $\mathrm{Zn}$ & 105 \\
\hline & & $\mathrm{Zr}$ & 171 \\
\hline
\end{tabular}

Table 1: Major and trace element concentrations of Pebble A (data courtesy Tobschall, Erlangen; sample reference HL-A RF_9089). 
The results match well with the chemical composition of alkali olivine basalts. This can be seen from the $\mathrm{SiO}_{2}(45.7 \mathrm{wt} \%), \mathrm{MgO}(10.0 \mathrm{wt} \%)$ and $\mathrm{CaO}(9.68 \mathrm{wt} \%)$ contents and the total alkalis $\left(\mathrm{Na}_{2} \mathrm{O}\right.$ $\left.+\mathrm{K}_{2} \mathrm{O}=3.51 \mathrm{wt} \%\right)$. The $\mathrm{Na}_{2} \mathrm{O} / \mathrm{K}_{2} \mathrm{O}$ ratio amounts to 2.02 , reflecting the sodic nature of the rocks (sodic series). The general alkalic nature of the rock is seen also from their low $\mathrm{Y} / \mathrm{Nb}(0.77)$ and low $\mathrm{Zr} / \mathrm{Nb}$ (5.5) ratios. It appears that the magma resulting in this rock was primitive in nature as reflected by its low $\mathrm{SiO}_{2}(<50 \mathrm{wt} \%)$ and high $\mathrm{Cr}$, $\mathrm{Ni}$ and $\mathrm{MgO}$ contents. These concentrations may reflect the low degree of partial melting and limited magma fractionation. However, the Ba (1446 $\mathrm{ppm}$ ) concentration is unusually high for this type of basalt (it is usually around $200 \mathrm{ppm}$ ). Such a high concentration is difficult to explain. But it may originate from a secondary source (Al-Malabeh \& Al-Zyoud, in preparation). The concentration of $\mathrm{Y}(24 \mathrm{ppm})$, the high $\mathrm{TiO}_{2}$ and the high $\mathrm{Zr} / \mathrm{Y}$ ratio may reflect that the magma originated in a garnet peridotite mantle source (Frey et al., 1978; Claque \& Frey, 1982). However, this interpretation needs further investigation. The total Fe content amounts to $12.18 \%$. It is this iron which stays behind as iron oxide due to the disintegration of the volcanic minerals as described above.

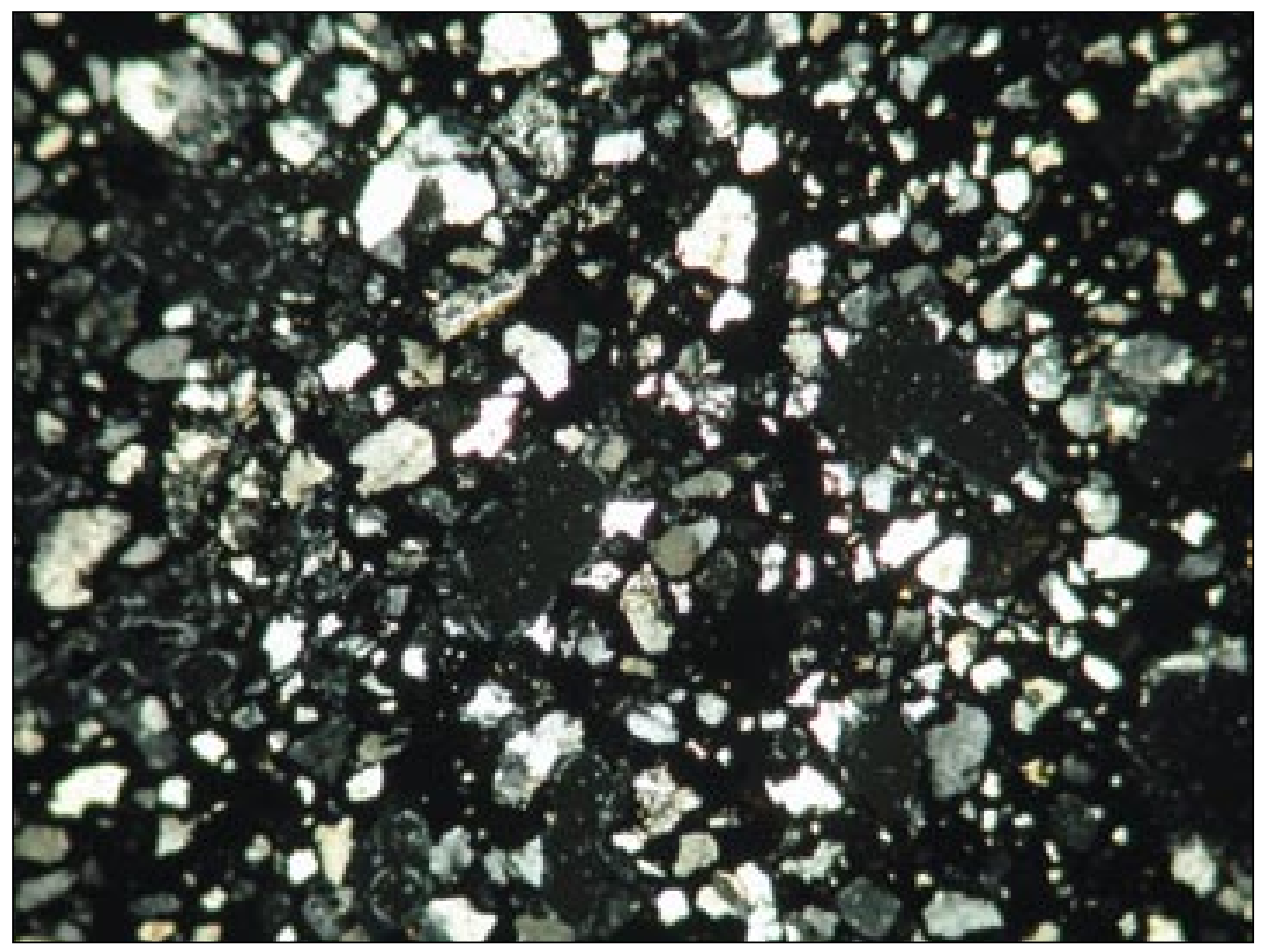

Fig. 9: Pebble D, a feldspatic sandstone with a dark brown matrix (plane light, magnification $10 * 4)$. 


\section{CONCLUSIONS}

Basalt is very susceptible to weathering and hydrothermal alteration. The most common alteration process is iddingsitization, transforming the olivines progressively into iddingsite that in the most extensively altered specimens replaces the olivine entirely as pseudomorphs. Iddingsite as a mineral is amorphous. It occurs in many colors: light brown, dark brown and red. It forms under oxidizing conditions at temperatures below $140^{\circ} \mathrm{C}$ (Barke \& Haggerty, 1967). The olivines are altered principally through leaching, which results in the removal of magnesium and the addition of water and some iron. The chemical reactions are usually complex and involve hydration and oxidation. The iddingsite actually consists of an intimate mixture of several distinct minerals. X-ray diffraction analyses of iddingsite of basaltic rocks (Al-Malabeh, 1993) show that the mineral goethite (FeO.OH) is an important component. Hematite $\left(\mathrm{Fe}_{2} \mathrm{O}_{3}\right)$, as well as a silicate phases related to smectite may be present. However, detailed description and discussion of basalt alteration is beyond the scope of the present study. The alteration mechanism is subject of many publications (e.g., Gutzmera et al., 2003).

The Herbstlabyrinth pebbles show the entire spectrum of the alteration of basalts from rather fresh and only locally transformed olivines to a completely altered state, in which only iron-oxide phases remain. These iron-oxides occur as iron nuggets ("Bohnerze") which are highly resistant to further weathering. Consequently they can form deposits in karst depressions and caves. The iron nuggets of the Herbstlabyrinth are therefore derivatives of basalts and did not form through the oxidation of pyrites.

Chemical study of the fresh basalts shows that they are of alkali type and belong to the sodic series. They appear to be generated from primitive magma and did not undergo high fractionation. They are thought to originate by a limited partial melting of garnet peridotite mantle source.

\section{ACKNOWLEDGEMENTS}

We thank the SAH for organizing an excursion into the Herbstlabyrinth, participants were: I. Dorsten, A. Hüsner, U. Fricke, E. and N. Schuhose. Our thanks also go to Prof. Dr. H .J. Tobschall, Erlangen, who provided a XRF analysis.

\section{REFERENCES}

Al-Malabeh, A., 1993: The volcanology, mineralogy and geochemistry of selected pyroclastic cones from NE-Jordan and their evaluation for possible industrial applications. -Ph.D thesis. Erlangen University-Germany, $300 \mathrm{pp}$.

Al-Malabeh, A. \& Al-Zyoud, S. ,(in preparation): The petrogenesis of Al-Hasimiyya Basaltic rocks, Jordan. - J. Asian Sci., submitted.

Barker, I \& Haggerty, S.E., 1967: The alteration of olivines in basaltic and associated lavas, part II, intermediate and low temperature alteration. -Contr. Mineral Petr., 16: 258-273.

Bartz, J., 1957: Bohnerze im nördlichen Oberrheingebiet. - Z. Deut. Geol. Ges. 109: 73-76.

Dorsten, I., Hülsmann, T., \& Hüser, A., 2005: Das Herbstlabyrinth-Adventhöhle-System - die erste Riesenhöhle Hessens. - Mitt. Verb. deut. Höhlen- u. Karstforsch., 51(1): 4-10.

Clague, D. \& Frey, F., 1982: Petrology and trace element geochemistry of the Honululu volcanism: 
implications for the oceanic mantle below Hawaii. -J. Petrol., 23: 447- 504.

Frey, F., Green, D. \& Roy, S., 1978: Integrated models of basalt petrogenesis: A study of quartz tholeiites to olivine melilites from southeastern Australia utilizing geochemical and experimental petrological data. -J. Petrol., 19: 463- 513.

Gutzmera, J., Banks, D., Lüders, V., Hoefs, J., Beukes, N. \& von Bezing, K., 2003: Ancient subseafloor alteration of basaltic andesites of the Ongeluk Formation, South Africa: implications for the chemistry of Paleoproterozoic seawater. -Chemical Geology, 201: 37-53.

Hill, C.A. \& Forti, P., 1997: Cave Minerals of the World. - Nat. Speleological Soc., Huntsville, Alabama, 463 pp.

Kayser, E., 1907: Erläuterungen zur Geologischen Karte von Preußen, Lief. 101, Bl. Herborn. - Königl. Preuß. Geol. Landesanst., Berlin, 73 pp.

Seemann, R., 1979: Die sedimentären Eisenvererzungen der Karstgebiete der Nördlichen Kalkalpen. -Ann. Naturhist. Mus. 82: 209-290. 